\title{
VALUE CAPTURE INSTRUMENTS AS AN INFRASTRUCTURE PROJECT FINANCING ALTERNATIVE FOR RAIL-BASED MASS TRANSPORTATION: QUALITATIVE STUDY FROM THE GOVERNMENT PERSPECTIVE
}

\author{
Ario Bintang Koesalamwardi ${ }^{1 *}$, Susy Fatena Rostiyanti ${ }^{1}$, Ravli Thaufiq Reksapernata ${ }^{1}$ \\ ${ }^{1}$ Construction Engineering and Management Program, Universitas Agung Podomoro, \\ Jakarta Indonesia
}

(Received: September 2020 / Revised: November 2020 / Accepted: December 2020)

\begin{abstract}
Increasing the mobility of the working class in urban areas will increase their productivity, which in turn will increase the economic output of the region. This can be achieved by providing a means of mass transportation infrastructure that is fast, affordable, and efficient i.e. rail-based mass transportation. However, the Ministry of National Development Planning estimated there is an infrastructure-funding gap of 4,321 trillion rupiahs to achieve Indonesia's development targets. Inviting the private sector to participate in infrastructure development investment in Land Value Capture (LVC) scheme becomes one of the solutions that need to be studied further. LVC is considered a promising infrastructure financing scheme for the private sector's investment. However, one of the challenges faced by the government in the application is to identify feasible instruments to capture the value of the land. This study aims to find LVC instruments that are feasible from the perspective of the Indonesian government agency. In-depth interviews with experts from government agencies were conducted to explore the possibilities of LVC instruments that can be applied in Indonesia for mass transportation infrastructure development in urban areas. The result shows that most of the Key Informants (KIs) agree that density bonuses and joint development instruments are applicable LVC schemes for Indonesia. It can be concluded from the analysis that these instruments are better prepared due to the availability of regulations that are mutually beneficial for both the government and the private sector, and has a simpler bureaucratic process.
\end{abstract}

Keywords: Land Value Capture; Infrastructure Financing; Financing Instruments; Qualitative Study; Government Perspective

\section{INTRODUCTION}

In an urban area, where most economic activity is centered, mobility is very important to support the productivity of city dwellers so that economic output can increase simultaneously. However, urban areas often experience classic problems related to traffic congestion, which hinder people's productivity and ultimately results in regional economic losses. In order to overcome the problem, mass transportation infrastructure development is one of the solutions for local governments to increase the mobility and productivity of city residents. Mass transportation infrastructure that is excellent for urban areas is a rail-based mass transit, which in a few years back construction was intensified by some local governments.

*Corresponding author's email: ario.bintang@podomorouniversity.ac.id, Tel. +6281280008471

DOI: https://doi.org/10.32783/csid-jid.v3i2.151 
Rail-based mass transportation provides great speed, security, and capacity to serve the mobility needs of city residents (Berawi et al., 2019; Rahman et al., 2018). With more and more residents shifting from private vehicles to public transportation, urban traffic congestion that is detrimental to the economy can be minimized and encourage economic growth (Sugiarto et al., 2020).

Infrastructure development has been proven to increase the competitiveness of a country's economy (Mishra et al., 2016). The central government along with local government are necessary to invest in infrastructure development to boost the economy. The National Development Planning Agency (2019) has calculated that the total investment needed for infrastructure development to support national economic growth in 2020-2024 is 6,445 trillion rupiahs. However, government and State-Owned Enterprises (SOEs) can only meet 58\% of the total investment needs, thus the remaining $42 \%$ will be offered to the private sector. The infrastructure-financing gap proposes to the private sector through the Public-Private Partnership (PPP) scheme. While the scheme seems attractive for most infrastructure development, PPP implementation in urban rail-based mass transportation infrastructure projects is considered difficult. The problem arises in financing the operational phase, due to the ridership issue (Carpintero \& Petersen, 2014; Li \& Love, 2019). Thus, the government needs to seek another innovative approach in financing infrastructure projects, especially urban rail-based mass transportation.

One of the infrastructure funding schemes that is essential to be assessed is called Land Value Capture (LVC) (Indra, 2019). The LVC infrastructure-funding scheme depends on several important factors of success, especially the establishment of a business model that is mutually beneficial for the parties involved (Dentiala \& Koesalamwardi, 2020). There are two bases in infrastructure investment with LVC approach; namely development base and tax base. Each basis has several types of funding instruments. In Indonesia, one of the challenges in the implementation of LVC scheme especially for rail-based transportation infrastructure is that there are no clear funding instrument(s) suitable among the available instruments. Therefore, this study aims to define LVC instruments that can capture the added value of the land from the perspective of government agencies by comparing the instruments and the possibility of its application based on the availability of policies. This study will use a qualitative research approach to obtain detailed information from a series of structured interviews with several government parties that organize and plan infrastructure development. A qualitative approach is used because not many infrastructure projects use this funding scheme, and LVC is still in the stage of policy studies at the government level.

\section{LAND VALUE CAPTURE}

\subsection{Definition}

Before discussing the definition of Land Value Capture, it is necessary to first emphasize the elements of a capitalized "value" land. Fensham and Gleeson (2003) explained that there are 3 elements of "land value", i.e: (1) "infrastructure" development that serves private property, which is financed from user fees, e.g.: water distribution, electrical, waste disposal, etc.; (2) social infrastructure financed by the government through tax collection, e.g.: schools, hospitals, public transportation network; and (3) urban externalities, e.g.: markets, access to services, suppliers, etc. This explanation is then reinforced by Anantsuksomsri and Tontisirin (2015) findings, where public transport infrastructure, especially rail-based ones can increase land value. The LVC infrastructure-funding scheme takes part or all of the increase in land value because of the existence of transportation infrastructure that increases the accessibility of the land, to fund the construction of mass transportation infrastructure mentioned before (Li \& Love, 2019). Thus, the LVC scheme is a monetization mechanism for land value increases by collecting a number of 
contributions from landowners (property developers), equivalent to the additional benefits that they will gain from the existence of this transportation infrastructure (Australian Government, 2016; TFL \& GLA, 2017). To utilize the added value of the monetized land, there are 2 categories of LVC scheme, namely development-based and tax-based LVC. Each category has instruments that can be used to utilize the added value of land as a source of funding for transportation infrastructure development (Suzuki et al., 2015; Kumar Jillella \& Newman, 2016; McIntosh et al., 2015). Those instruments are:

\section{Development based LVC}

a. Joint development. Government cooperation (usually represented by transit agencies) with property developers to build and develop station facilities and areas that intersect those facilities. Each party can contribute financially and physically to the construction of station and area facilities.

b. Branding rights on public transportation facilities. The private sector that contributes to the construction of some public transportation facilities has the right to name the public transportation facilities, such as stations, with their trademarks or brands.

c. Density bonuses / Air rights sale. The government sells the rights to increase the Floor Area Ratios (FARs), and/or building height, exceeding those previously stipulated in the regional regulations.

d. Local parking levy. Utilization of revenue generated from parking fees available, and used as operational funding for public transportation infrastructure facilities.

e. Urban redevelopment schemes / Land readjustments. Some landowners pool and contribute a portion of their land for sale to finance the construction of mass transportation infrastructure that passes through their land. Landowners and property developers form cooperative entities to consolidate part of the land into a single piece of land for the construction of a Transit-Oriented Development area. Local governments modify the zoning regulations and increase the land FARs

\section{Tax based LVC}

a. Tax holiday. The contribution of the private sector to the construction of public infrastructure is rewarded by the government with the exemption of tax collection for a certain amount of time.

b. Betterment charges and special assessments. Additional tax levied by the government on the value of land and/or buildings that have increased due to receiving benefits from public infrastructure.

c. Tax increment financing. An additional property tax within an area to be rebuilt by the public investment financed by municipal bonds against the expected increase in property taxes.

\subsection{Application of $\mathrm{LVC}$ in Other Countries}

Here are 2 good practices of LVC infrastructure funding scheme (Suzuki et al., 2015):

1. Hong Kong, Rail plus Property project.

Hong Kong's Rail plus Property program runs with the granting of the Hong Kong government's land development rights to the Hong Kong-Owned Enterprise, MTR Corporation (MTRC). Until 2000, MTRC was fully owned by the Hong Kong special regional government, until then $23 \%$ of its share ownership was released to the public. After obtaining a land development rights grant, the MTRC benefits from saving land acquisition costs and can focus its efforts on developing, managing property, and operating rail transportation facilities. Most of MRTC's revenue comes from its property development line, which in turn can finance the operations of its train transportation facilities without relying on subsidies from 
the Hong Kong government (Cervero \& Murakami, 2009; Murakami, 2012). This relationship can be seen in Figure 1.

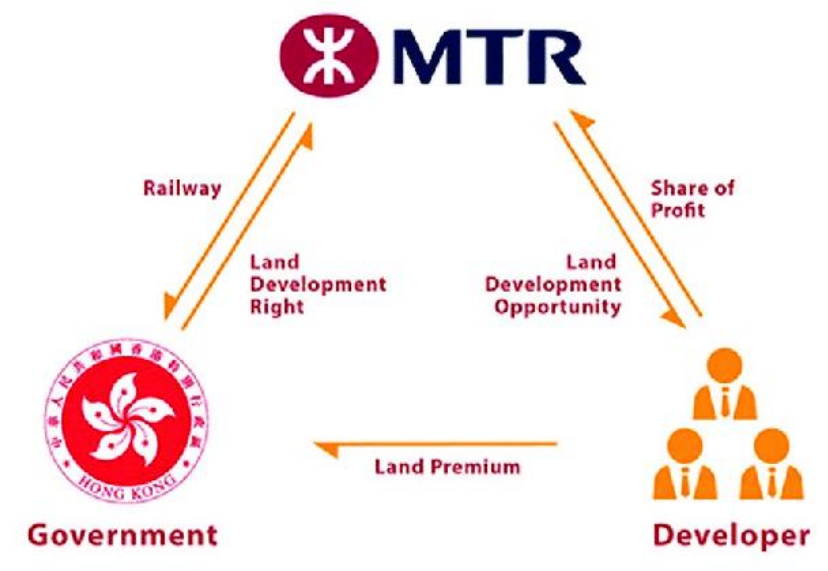

Figure 1. MTR and the rail plus property scheme

(MTR, 2015; He et al., 2018)

2. Land readjustment (Town Planning) scheme in Gujarat, India.

Almost similar to Japan's land readjustment scheme, India utilizes this scheme to finance the development of urban infrastructure and public facilities. Although in India this scheme is named Town Planning (TP) scheme. The TP scheme consolidated all the land and returned it to their owner after the land was reshaped in proportion to use a portion of the land for public purposes. The process of land readjustment is initiated by the government planning agency. Together with the landowners, the government agency plans the reshaping of the land parcels. With this, the urban planning authority can have an affirmative control to design and develop the area. By using value capture financing instruments e.g. development charges and sale of the reserved land parcel, the development authority can finance the development of public service infrastructure. Moreover, the development authority can sell the reserved plots to finance the whole TP scheme (Byahut \& Mittal, 2017; Jain, 2019).

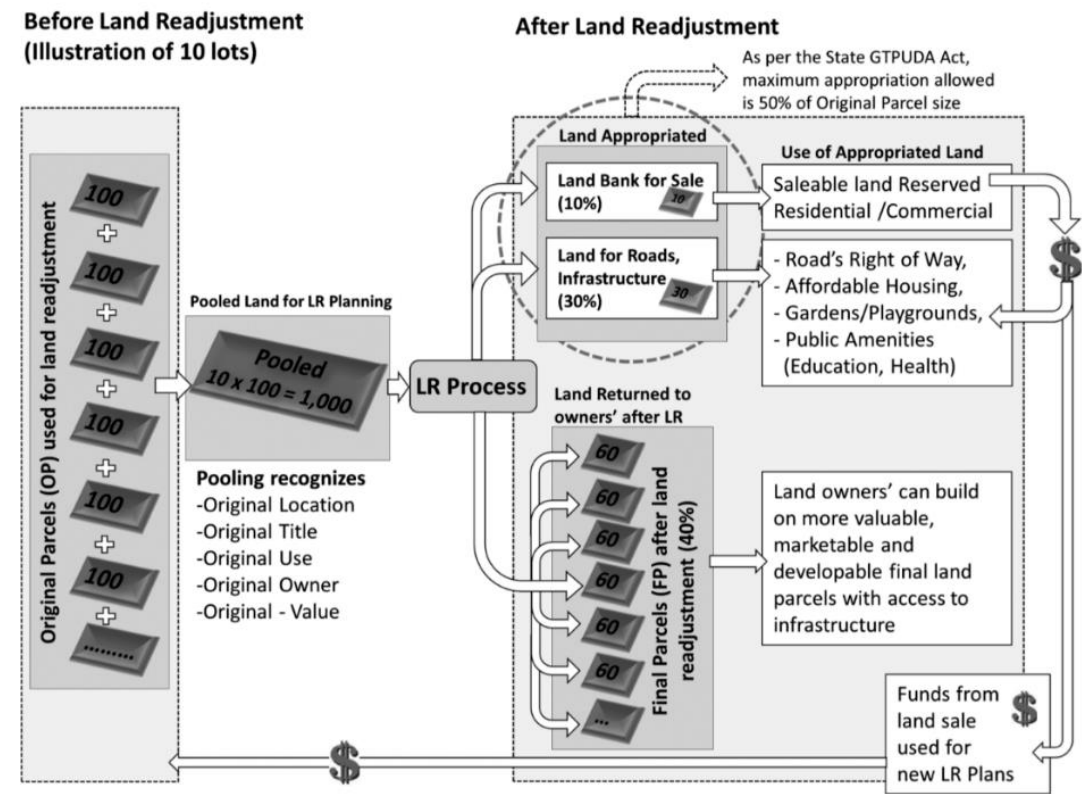

Figure 2.Land readjustment (town planning) scheme in India

(Byahut \& Mittal, 2017) 


\section{METHODOLOGY}

\subsection{Study Design}

Studies on the application of the LVC funding scheme in Indonesia by academics are still very rare. This is because this scheme is still in its early stages of study by the government agencies so that not many infrastructure projects in Indonesia have used the LVC funding scheme (Indra, 2019). Based on the research question of "what LVC instruments can be applied to rail-based mass transportation infrastructure projects in Indonesia," the research requires explorative study. One of the explorative characteristics that were considered in designing this study was the lack of control over sample responses. However, the design of the research strategy must still be able to focus on events, phenomena, or cases that are currently being studied (Yin, 2009).

Before compiling a list of interview questions, a literature study was carried out to look for various LVC instruments that have been used in various transportation infrastructure projects in the world. A literature study is carried out by searching a valid and trusted scientific journal database with the help of the google scholar search engine. The search for journals describing LVC instruments is limited to a maximum of 10 years. The keywords used are "Land Value Capture" OR "Value Capture" OR "Land Value" AND "Infrastructure Financing" OR "Infrastructure Project Financing" OR "Business Model" OR "Business Model Development".

This list of discovered instruments will then be processed into a list of questions to get information that can answer research questions. The instruments that will be asked from interviewees are as described in the previous literature study section. To ensure the list of instruments and questions used are valid, experts from academia validate the list. Academic validator criteria used are: (1) experience in research in infrastructure and or project funding; (2) have already published scientific journals at the international level; (3) has obtained a master's degree in a related field.

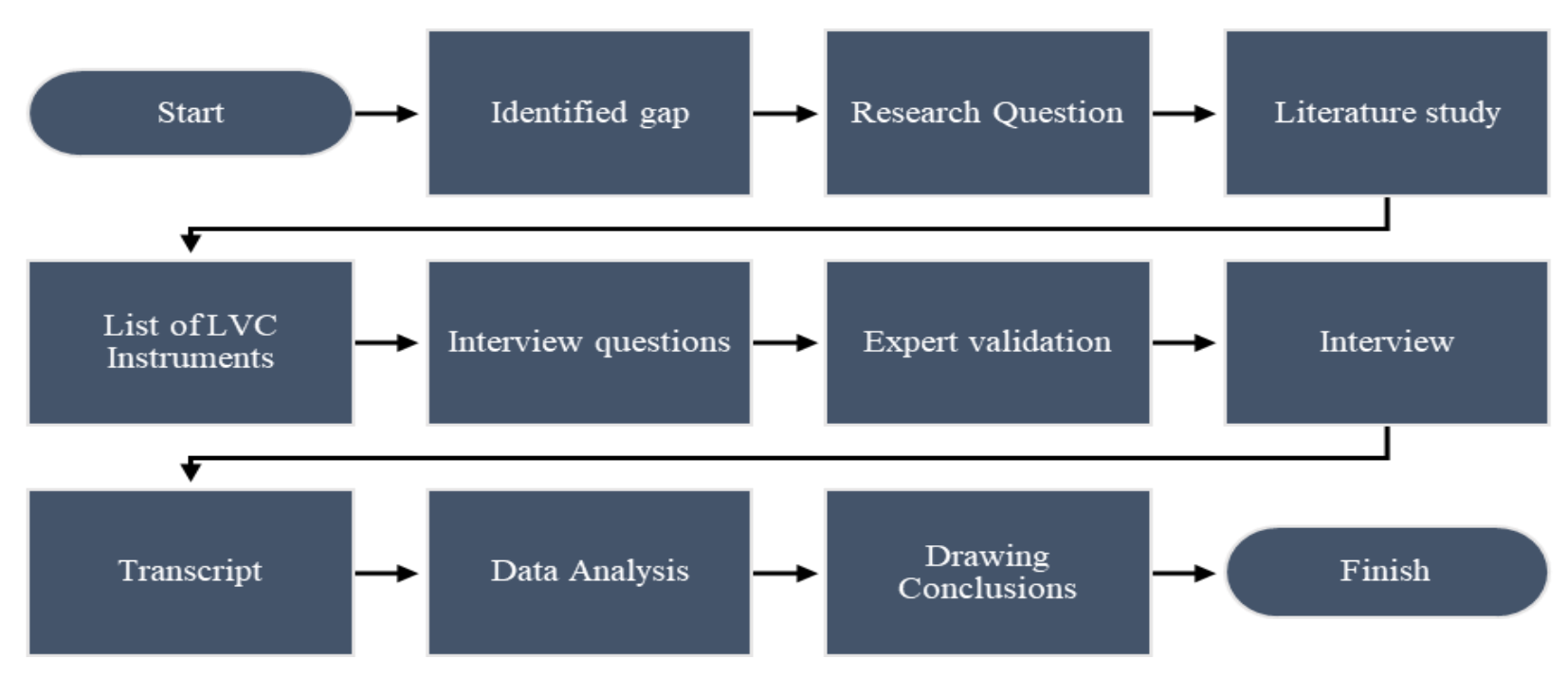

Figure 3. Research strategy flowchart

This study is a qualitative study using structured interview methods to obtain in-depth and detailed information that identifies and defines LVC infrastructure funding instruments that can be used in Indonesia. Structured interviews will use open-ended questions to explore explanatory responses. based on the interviewees' knowledge, expertise, and experience. Interviewees are planners, experts, and decision-makers from various directorates in the National Development Planning Agency (Badan Perencana Pembangunan Nasional). The information obtained from the 
interviewees is very important to identify and describe the LVC instruments that can be used in Indonesia from the perspective of policymakers.

An explanation of the recruitment of interviewees will be explained in the following sections.

\subsection{Selection and Sampling of Interviewee}

The study took data from in-depth interviews with 8 Key Informants (KIs), where all KIs work in 2 directorates of the National Development Planning Agency, namely the Directorate of Public-Private Partnership (PPP) and Directorate of Transportation. Each of the KI has a different job title, but they work in the directorates of the agency that arranges transportation infrastructure project planning and financing schemes.

Table 1. Key informants data

\begin{tabular}{cl}
\hline Key Informant (KIn) & \multicolumn{1}{c}{ Position } \\
\hline KI1 & Junior Planner \\
\hline KI2 & Associate Planner \\
\hline KI3 & Monitoring Expert \\
\hline KI4 & Law and Regulation Expert \\
\hline KI5 & Project Management-PPP Financing Expert \\
\hline KI6 & Director of Transportation \\
\hline KI7 & Principal Planner \\
\hline KI8 & Principal Planner \\
\hline
\end{tabular}

Because the nature of the object of this study, the LVC scheme, is very special and unknown to many people, the sampling method used is purposive sampling. All KIs are selected based on certain criteria, they are: (1) have work experience in national infrastructure project planning at least 5 years; (2) graduated with a Master Degree in project management, infrastructure management, macroeconomics, or state law from reputable universities; (3) certified as expert or professionals from national or international accredited certification body; (4) holds positions as experts, consultants, and/or decision-makers in national infrastructure project planning and development. The following table shows information related to KIs. Some information about KIs is not displayed in this table to protect anonymity.

\subsection{Data Collection}

Data collection was carried out with an interview process that explored the knowledge of the informants about the existing LVC instruments.

Questions will refer to the applicability of the instrument and the presence or absence of an overarching regulatory instrument. The interview process is conducted remotely with an online meeting platform. The use of this platform will facilitate the recording process of the interview process because the video conversations can be recorded on computers' hard disk. In addition, due to the outbreak of COVID-19, the health protocol recommends that interviews be conducted remotely. In the event of a disruption in internet connection which caused audio communication is interrupted, then the answer to the question can be typed by KIs in the chat room. All interactions in the chat room can also be recorded and can be used as minutes to clarify answers. 


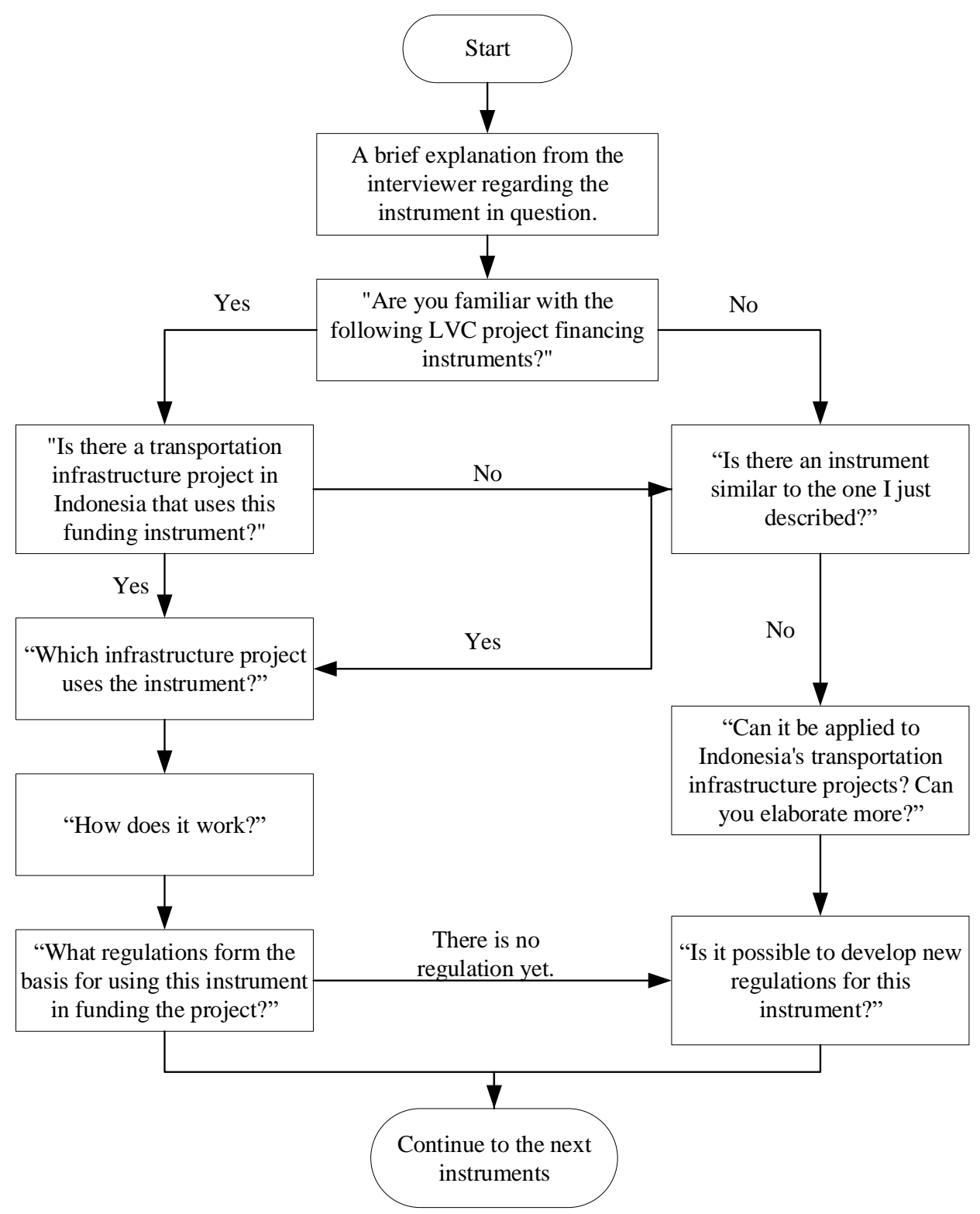

Figure 4. Interview guideline

Interviews run for at least 30 minutes, depending on the KIs response. The questions asked have a dynamic structure, adjusting to the KIs response. The Figure 4 is the interview guideline flowchart.

\section{ANALYSIS AND RESULTS}

\subsection{Joint Development}

When discussing the joint development instrument, almost all interview respondents, 7 out of 8 , said the LVC joint development instrument could be applied in Indonesia. However, only 4 out of 7 sources can answer the existence of regulations governing the LVC joint development instrument. They also conveyed several additional notes regarding the joint development application. 
The implementation of the collaborative infrastructure development scheme among government and business entities, i.e. private sectors, is more about cooperation. The government does not grant land for infrastructure or its facilities or gives the right of land use to developers. This is as revealed by $\mathrm{KI} 2$,

"In the collaboration scheme between the government and business entities, this instrument does not directly provide land to the developer. Rather it is directed towards land use either carried out by the government or in collaboration with the developer."

In joint development as an instrument to finance infrastructure development, the government, through the National Development Planning Agency, must have an infrastructure development master plan, e.g. transportation master plan, railway master plan, urban mobility plan study. The master plan must include parties that can be invited to work together, as stated by KI1 and KI3. A similar sentiment was also stated by KI7 and KI8 regarding the need for transportation master plans, rail lines, and urban mobility studies. The master plan can be elaborated in the National Medium-Term Development Plan so that the application of the LVC infrastructure funding scheme with its chosen instruments can be taken into consideration from the start. The full statement by KI7 on this matter is as follows,

"The National Development Planning Agency developed the National Mid-Term Development Plan as a reference for the Ministry, especially in the transportation sector which is the Ministry of Transportation for preparing a 5-year strategic plan and later is expanding into annual work plans."

KI4 stated that a joint development instrument has been applied in Indonesia, under the name Utilization Cooperation (Kerjasama Pemanfaatan). The intended use can be in the form of rent or lease land use. Technical implementation of the cooperation regulated by Government Regulation No. 28 of 2018 and Presidential Decree No. 38 of 2015 on Government and Business Entity Cooperation in the Provision of Infrastructure.

\subsection{Branding Rights on Public Transportation Facility}

Only 2 out of 8 respondents believe that the granting of branding rights to public transportation facilities can or have been applied in Indonesia. The small number of positive responses to this instrument is proportional to the number of respondents who explicitly stated the existence of regulations governing this instrument. KI4 stated that this instrument could be applied in Indonesia. However, its implementation is only based on business-to-business agreements between transportation facility operators and business entities. The majority of respondents who stated there was no government regulation governing the implementation of this instrument also confirmed the limited application of this business-to-business instrument.

The implementation of this funding instrument, which is limited to business-to-business, affects the ability of the funders. KI5 stated that this LVC instrument is only able to finance the operation and maintenance costs of public transportation facilities that are branded with the business entity that is invited to cooperate.

\subsection{Density Bonuses / Air Rights Sale}

When discussing this instrument, almost all interview respondents (7 out of 8) stated that this LVC instrument could even have been applied in infrastructure development in Indonesia. KI1, $\mathrm{KI}$, and KI3 stated that density bonus has been carried out in several government-owned apartments or affordable housing projects, which aims to increase revenue. However, the three interviewees did not mention who would receive the additional income as well as the possible use of this additional for infrastructure development. KI4 added that this instrument has been widely applied in metropolitan areas such as Jakarta. A density bonus as a funding instrument is 
granted when a property developer builds a more than 16 floors building in Jakarta. Local regulations determine the number of density bonuses (i.e. additional FARs) given to the developer. The central government only provides basic references based on the perspective of the Ministry of Public Works-Public Housing. The benefit from the density bonuses instrument for transportation infrastructure financing also still requires a more in-depth study, according to KI5.

Interviewees from the directorate of transportation provided a more detailed view of this instrument. KI6 explained,

"For density bonuses, we can take the example of mass rapid transit in Hong Kong. The Hong Kong government grants the land to be developed into a commercial area and managed by the Hong Kong-Owned Enterprise, MTR Corporation (MTRC). The revenue from the development of commercial and farebox (tickets of the transportation service) is meant to finance the capital and operational expenditure of this system. Additional note, MTRC cannot afford to continue to rely on the benefits of regional development and tickets, if it wants to continue that way then it must increase the rate. If the tariff is increased, the price is no longer competitive with private transportation. So, government policies must be enforced. In the end, the government had to subsidize the MTRC. Whether this is an LVC scheme or not, depends on what we define LVC for. Philosophically, it also means that the operator benefits from the land and development rights grant by the government when the land value is still low. After being developed with joint funding, it became a business, and the profits earned are returned to the public sector. From a technical point of view, it is not an LVC, because there are additional taxes that are imposed on the landowner. So it is like internally integrated."

\subsection{Local Parking Levy}

When it comes to local parking levy instruments, the responses are mixed. KI1, KI4, and KI5 mentioned that there is a regulation for this instrument which is DKI Jakarta Regional Regulation no. 5 of 2012. However, KI5 argues that this instrument cannot be used for financing the capital expenditure of the infrastructure project. The revenue from the local parking levy is categorized as regional income, like the non-farebox revenue. KI6 and KI8 do not recommend the use of the local parking levy as an infrastructure funding instrument. They find that the implementation of this instrument tends to raise conflicts of interest. Usually, the conflict occurs in terms of transparency of parking revenue management among stakeholders.

\subsection{Urban Redevelopment Schemes / Land Readjustments}

Only 2 out of 8 respondents clearly stated this instrument can be applied in Indonesia but none of them can tell exactly the governing regulation. KI4 and KI5 explained that this instrument can be applied in Indonesia. Additionally, KI5 explained that the implementation of this LVC instrument will be difficult because the government will be burdened with the obligation to replace the land. The KI5 opinion regarding the obstacles in the application of this instrument was enforced by KI3 which stated that this instrument could not be applied in Indonesia, due to some bureaucratic restrictions. These restrictions cause some hesitancy among stakeholders involved in infrastructure project planning to use this instrument. The bureaucratic processes can reach the level of the regional legislature.

Respondents from the transportation directorate, KI6, and KI7 did not respond to the application of the instrument in Indonesia. KI6 explained that in order for this instrument to be successfully applied, applications of land readjustment in Japan become a reference for best practice. A social approach in the land acquisition process for transportation infrastructure will make the process and field implementation easier. KI7 added, apart from the issue of a social approach to the 
community, there are institutional issues in the application of this LVC instrument. In theory, this LVC instrument looks convenient to apply, but in reality, there are quite complicated institutional issues and technical authority for implementation. The conflict of interest will get more and more complicated when the private sector starts to be involved. Best practices for socio-economic conditions in Indonesia still need to be reviewed.

\subsection{Tax Based Value Capture}

The government for funding the construction of public facilities including mass transportation infrastructure collects taxes. The value of land tax in Indonesia will of course follow the Sales Value of the Tax Object (Nilai Jual Objek Pajak, NJOP) that has been determined by the government through the Ministry of Finance. When the value of land around the development of transportation facilities increases, the value of the surrounding land will consequently increase, and landowners will be subjected to higher taxes. According to KI5, Indonesia has implemented tax-based land value instruments, as a special assessment and or tax increment financing (TIF). On the other hand, the tax holiday has existed since 2018 as stated, in the Minister of Finance Regulation No. 35 of 2018 on Granting of Corporate Income Tax Deductions. However, KI5 cannot confirm whether the tax holiday can be given to property developer business entities that contribute to infrastructure development. This also stated by KI1 and KI2, that there is an unclear possibility that this instrument can be applied since no property development business entity has proposed it. KI4 even suggested using this instrument because the country is still very dependent on tax revenues.

\section{DISCUSSIONS}

This qualitative study focuses on the perspective of government agencies responsible for planning infrastructure development including funding schemes.

Table 2. Summary of responses

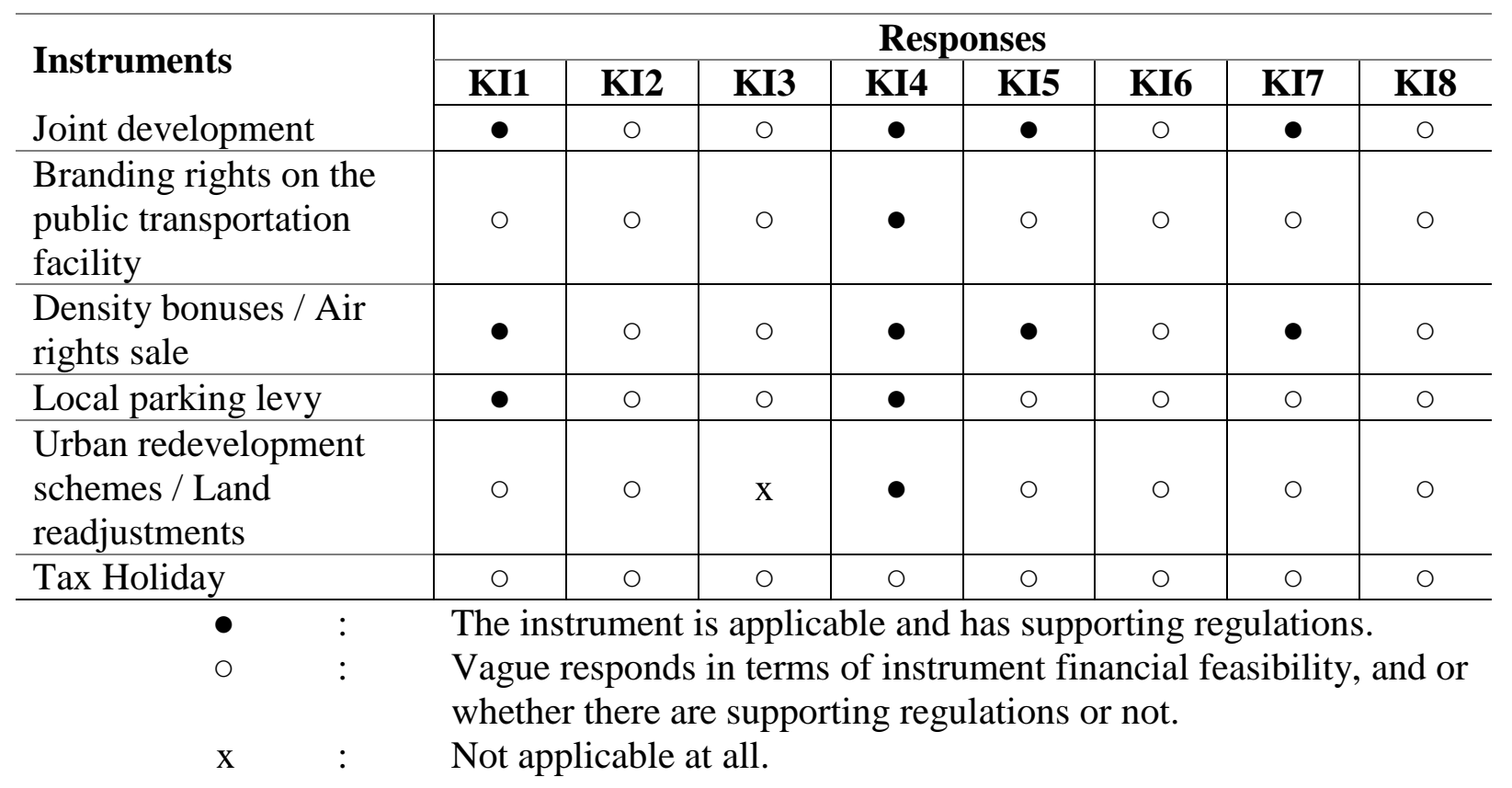

The findings of this study will reveal which LVC instruments have technical and regulatory support and government agencies. The interviewees gave various responses in terms of their understanding of applicability, technicality, philosophy, and regulations related to the LVC 
instruments in question. Although some of the responses were vague, there is only one contradicting response when discussing development-based LVC instruments.

Table 2 above shows that the two most preferable development based LVC instruments are the joint development and the density bonus. Half of the respondents firmly stated that this instrument was applicable and had supporting regulations. Apart from that, there is no clear statement stating that the two instruments cannot be applied in financing mass transportation infrastructure. Responses other than positive responses seem more neutral and not contradictory.

\subsection{Joint Development of Poris-Plawad TOD Under Utilization Cooperation}

In Vietnam due to the strong government regulations on development laws, i.e. construction law, urban development regulation decree, urban planning, urban upgrading law from 2004 to 2017 , the Vietnam government successfully mobilized their assets and cooperate with business entities through a joint development scheme to develop Da Nang, Binh Duong, and Ho Chi Minh (Nguyen Ngoc \& Tran Quang, 2021)

Fortunately, like the Vietnam government, the Banten provincial government already has a legal framework that is strong enough to develop TOD Poris-Plawad together with private property developers in a Joint Development scheme. The government through the Jabodetabek Transportation Management Agency (BPTJ) of the Ministry of Transportation is working with the private sector to develop this area in a project valued at Rp. 1.7 Trillion. The TOD area is planned to be supported by several modes of mass transportation, including intercity buses within provinces, intercity buses between provinces, bus rapid transit, Light Rail Transit (LRT), electric rail trains (Commuter Line), airport trains (Railink). This joint development project was initiated by the private sector, while the government acts as the party in charge of Utilization Cooperation of government-owned land with the private sector. According to Government Regulation No. 28 of 2018 and Presidential Decree No. 38 of 2015 on Government and Business Entity Cooperation in the Provision of Infrastructure, the private entity that will cooperate in this scheme must meet several criteria, such as the property developed must be technically integrated with the master plan in the sector concerned, be economically and financially feasible, and have sufficient financial capacity to finance the implementation of infrastructure provision. The regulation also regulates the contribution of the government as the responsible party in charge of land acquisition and licensing.

\subsection{Public Facilities Project Funding by Developers Contribution}

In Jakarta, there have been several public infrastructure projects funded by private contributions that have proposed additional FARs and/or building height. The Governor of DKI Jakarta Regulation No. 210 of 2016 has regulated this density bonuses/air rights sale instruments. Based on this regulation, not all property development projects can obtain permits for additional FARs or building height. One of the criteria is a building that has a function as a mixed-use area with the Transit-Oriented Development concept. The addition of FARs beyond the initial provision is certainly not free. Government with Governor Regulation No. 210 of 2016 in Article 6 paragraph 1 has the right to request a number of contributions from private property developers in the form of providing public infrastructure. However, the regulation has not stated that one of the contributions of providing public facilities that can be given is the mass transportation infrastructure. Several public infrastructure projects that are funded by a density bonus or air rights sale instruments include Semanggi interchange, 540 rented apartment units including public parks in Daan Mogot, another 840 rented apartments in Daan Mogot, rehabilitation of the General Election Committee building, and arrangement of the Old City Area of DKI Jakarta. This density bonus instrument can be used to finance the development of mass transportation infrastructure on a large scale, such as that carried out by the Indian government. In India, the 
transit and housing authorities work together benefiting the fund raised from the developers who get bonus density to build rail-based mass transportation infrastructure. This instrument is applied by the Indian government to all its mass transport infrastructure projects, whether rail-based or road-based (BRT) (Chava \& Newman, 2016).

\subsection{Other Potential LVC Instruments}

Of the following development-based LVC instruments, the respondents are mostly unsure in recommending them for various reasons. However, these instruments have potential if they are further developed. Instruments such as local parking levy and branding rights on public transportation facilities are considered unable to contribute so much to fund capital expenditure i.e. initial construction costs. However, these two instruments still provide benefits for both operators and the government. For operators, the branding rights on public transportation facilities can finance operational expenditures. This is confirmed by an interview with the Director of MRT Jakarta co., Director of MRT Jakarta co. said that naming rights are one of the largest contributions (33\%) in terms of non-farebox revenue (Zuraya, 2019). Like the previous instruments, the local parking levy also only contributed to a limited extent. Apart from the minimal contribution to funding, one of the things that makes an LVC instrument less desirable is the convoluted bureaucratic problem among different government agencies. The development planning government agencies in developing countries are likely to face when using the LVC land readjustment instrument. The land readjustment instruments involving many stakeholders. Apart from landowners, government agencies providing public facilities that can be involved in infrastructure development such as utilities, public transportation, environment, etc. can create complexity in the bureaucratic process (Jain, 2019). This problem will be faced when this instrument is applied in the field. Apart from institutional bureaucratic problems in the field, this instrument also has the potential for bureaucratic problems in terms of legislation. This is a problem the government will face, i.e. the executive, when it has to ask permission from the legislature to exchange state assets, in this case, is land. This has been regulated in Law number 1 of 2014, article 45, concerning the State Treasury.

The mechanism for tax collection from land, including land that has experienced an increase in value as a result of the construction of public infrastructure, already exists and is applied. This mechanism, although not given a name like Tax Increment Financing or Special Assessment, is already running following the prevailing tax regulations. What about tax incentives or tax holidays for business entities that contribute to the construction of public interest facilities? The requirements for business entities to apply for tax incentives or tax holidays are specified in the Minister of Finance Regulation No. 35 of 2018 on Granting of Corporate Income Tax Deductions. The contribution of property developers in building infrastructure to support the economy does not necessarily make property developers meet the requirements for a tax holiday. This is because, in Article 2 paragraph 2 of this regulation, contributions to infrastructure development are not considered the main business activity of a property development company. So that the government will not be allowed to offer tax breaks, even tax holidays to property developers who have contributed to the development of transportation infrastructure near their land.

\section{CONCLUSION}

In implementing an infrastructure funding instrument, especially one that invites private sector cooperation such as LVC, from the perspective of a national development planning government agency, at least 2 things are needed. Namely strong regulation, as well as financial feasibility that brings benefits for both the government and the private sector. One thing that the government avoids is the complexity of the institutional bureaucracy that can hinder cooperation in infrastructure development and economic growth. This study concludes that the LVC 
instruments, which are preferable for financing the rail-based mass transportation infrastructure project from the perspective of government agencies, are development-based LVC instruments, namely joint development and density bonuses or air rights sale.

The government through the Jabodetabek Transportation Management Agency (BPTJ) of the Ministry of Transportation and private property developer does the joint development LVC instrument already applied in the TOD project in Poris-Plawad, this joint development. In the utilization cooperation scheme supported by the Governor Regulation and Presidential Regulation, the two parties undergo the development of the Poris-Plawad TOD area which is integrated with various modes of mass transportation. The density bonus LVC instrument has been used by both the government and private developers, especially in DKI Jakarta. Although the contribution made by private property developers to get density bonuses (FARs) has not been widely used to fund the construction of mass transportation infrastructure which is relatively more expensive than other public facilities such as rental apartments, public parks, tourist areas, and government buildings, the applications of this LVC instrument on several public facilities project already shows that government regulatory support can persuade the private sector to contribute in funding the construction of public facilities. However, the potential of the fundraising power of this instrument has not been fully explored so that it can fund mass transportation infrastructure such as in India.

\section{ACKNOWLEDGEMENT}

The authors would like to acknowledge and thank the interviewees from the National Development Planning Agency for their time and willingness to be interviewed. All interviews were conducted remotely in order to undergo health protocols due to the COVID-19 outbreak. Interviews were conducted from 29 April to 3 June 2020.

\section{REFERENCES}

Anantsuksomsri, S., \& Tontisirin, N. (2015). The Impacts of Mass Transit Improvements on Residential Land Development Values: Evidence from the Bangkok Metropolitan Region. Urban Policy and Research. https://doi.org/10.1080/08111146.2014.982791

Australian Government. (2016). Using Value Capture to Help Deliver Major Land Transport Infrastructure: Roles for the Australian Government (Issue November). https://investment.infrastructure.gov.au/files/value_capture/Value-Capture-DiscussionPaper.pdf

Badan Perencanaan Pembangunan Nasional. (2019). Rancangan Teknokratik Rencana Pembangunan Jangka Menengah Nasional 2020-2024.

Berawi, M. A., Ibrahim, B. E., Gunawan, \& Miraj, P. (2019). Developing a conceptual design of transit-oriented development to improve urban land use planning. Journal of Design and Built Environment.

Byahut, S., \& Mittal, J. (2017). Using Land Readjustment in Rebuilding the EarthquakeDamaged City of Bhuj, India. Journal of Urban Planning and Development, 143(1). https://doi.org/10.1061/(ASCE)UP.1943-5444.0000354

Carpintero, S., \& Petersen, O. H. (2014). PPP projects in transport: evidence from light rail projects in Spain. Public Money \& Management, 34(1), 43-50. https://doi.org/10.1080/09540962.2014.865935

Cervero, R., \& Murakami, J. (2009). Rail and Property Development in Hong Kong: Experiences and Extensions. Urban Studies, 46(10), 2019-2043. https://doi.org/10.1177/0042098009339431 
Chava, J., \& Newman, P. (2016). Stakeholder Deliberation on Developing Affordable Housing Strategies: Towards Inclusive and Sustainable Transit-Oriented Developments. Sustainability, 8(10). https://doi.org/10.3390/su8101024

Dentiala, B., \& Koesalamwardi, A. B. (2020). Identifikasi Faktor-faktor Penentu Keberhasilan Skema Pendanaan Land Value Capture Pada Proyek Infrastruktur Transportasi Nasional: Studi Pendahuluan. Konferensi Nasional Rekayasa Dan Desain 2019, 64-72.

Fensham, P., \& Gleeson, B. (2003). Capturing value for urban management: A new agenda for betterment. Urban Policy and Research. https://doi.org/10.1080/0811114032000062164

He, S. Y., Tao, S., Hou, Y., \& Jiang, W. (2018). Mass Transit Railway, transit-oriented development and spatial justice: the competition for prime residential locations in Hong Kong since the 1980s. Town Planning Review, 89(5). https://doi.org/10.3828/tpr.2018.31

Indra, B. P. (2019). Keynote speech Seminar Kajian Kerangka Kebijakan Land Value Capture di Indonesia.

Jain, V. (2019). Examining the Town Planning Scheme of India and Lessons from Land Readjustment in Japan (No. 1037).

Kumar Jillella, S. S., \& Newman, P. (2016). Innovative value capture based rail transit financing: an opportunity for emerging transit cities of India. Journal of Sustainable Urbanization, Planning and Progress. https://doi.org/10.18063/jsupp.2016.01.003

Li, X., \& Love, P. E. D. (2019). Employing land value capture in urban rail transit public private partnerships: Retrospective analysis of Delhi's airport metro express. Research in Transportation Business and Management. https://doi.org/10.1016/j.rtbm.2020.100431

McIntosh, J., Trubka, R., \& Newman, P. (2015). Tax Increment Financing Framework for Integrated Transit and Urban Renewal Projects in Car-Dependent Cities. Urban Policy and Research. https://doi.org/10.1080/08111146.2014.968246

Mishra, A. K., Rao, G., Monga, A., \& Vishwanath, B. (2016). Assessing Competitiveness in Emerging Asian Economies: Role of Governance and Infrastructure and Lessons for India. Emerging Economy Studies, 2(1), 72-90. https://doi.org/10.1177/2394901515627732

Murakami, J. (2012). Transit Value Capture: New Town Co-development Models and Land Market Updates in Tokyo and Hong Kong. Proceedings of the 2011 Land Policy Conference "Value Capture and Land Policies," 285-320.

Nguyen Ngoc, H., \& Tran Quang, D. (2021). Collaborative Approach for Resource Mobilization Transformation in Vietnam. In L. T. T. Huong \& G. M. Pomeroy (Eds.), AUC 2019 (pp. 89107). Springer Singapore.

Rahman, H. Z., Berawi, M. A., Susantono, B., Miraj, P., Petroceany, J. S., \& Maya, R. (2018). Investigation of an Operation And Maintenance framework in the railway industry: A case study of the makassar-parepare. International Journal of Technology.

Sugiarto, S., Miwa, T., \& Morikawa, T. (2020). The tendency of public's attitudes to evaluate urban congestion charging policy in Asian megacity perspective: Case a study in Jakarta, Indonesia. Case Studies on Transport Policy, 8(1), 143-152. https://doi.org/https://doi.org/10.1016/j.cstp.2018.09.010

Suzuki, H., Murakami, J., Hong, Y.-H., \& Tamayose, B. (2015). Financing Transit-Oriented Development with Land Values: Adapting Land Value Capture in Developing Countries. In Financing Transit-Oriented Development with Land Values: Adapting Land Value Capture in Developing Countries. https://doi.org/10.1596/978-1-4648-0149-5

TFL, T. for L., \& GLA, G. L. A. (2017). Land value capture, Final report (Issue February). https://www.london.gov.uk/sites/default/files/land_value_capture_report_transport_for_lond on.pdf

Yin, R. K. (2009). Case Study Research: Design and Methods (4th ed.). Sage Publication.

Zuraya, N. (2019, November 28). MRT Jakarta Tawarkan Lima Hak Penamaan Stasiun. https://republika.co.id/berita/q1nl1k383/mrt-jakarta-tawarkan-lima-hak-penamaan-stasiun 